\title{
EFFECTIVE UTILIZATION OF STOCKPILED FOOD IN LOCAL GOVERNMENT STORAGE THROUGH FOOD BANKS IN JAPAN: REDUCTION OF FOOD WASTE
}

\author{
MIZUHO SATO ${ }^{1}$, MASARU NAKANO ${ }^{1} \&$ SHAHLA M. WUNDERLICH ${ }^{2}$ \\ ${ }^{1}$ Keio University, System Design and Management, Japan \\ ${ }^{2}$ Montclair State University, Nutrition and Food Studies, USA
}

\begin{abstract}
In Japan's local government storage there is a substantial amount of food that is prepared and stockpiled which when unused, goes to waste. This study served two purposes: (1) to evaluate the attitudes of Japanese citizens and supermarket employees towards providing stockpiled food to food bank clients and (2) assess the nutritional value of stockpiled food. This study will hopefully lead to food waste reduction and improve the availability of food to individuals in need. The results indicated the following: (1) Majority, 89.9\%, of participants answered, "I don't know" about the nutritional value of stockpiled food. (2) Half (54.5\%) said that they would cooperate with supermarkets. (3) Surprisingly, $76.7 \%$ of participants answered, "I don't know" when asked about their knowledge of food banks. However, the vast majority, $79.5 \%$, agreed that providing food banks with stockpiled food from local governments would be beneficial. (4) References were surveyed about the recent technological advances in preservation and the findings showed they could be effective for preserving fruits and vegetables in the supermarket. (5) There are some Japanese supermarkets that currently donate fruits and vegetables to food banks in need. (6) Supermarket employees were positive and willing to cooperate with food banks to provide them with fruits and vegetables. As a result of the positive attitudes of Japanese citizens and supermarket employees towards cooperating with food banks and supermarkets, there is potential for reduction of stockpiled food waste and taking proactive measures to improve the nutritional quality of the product in the food bank. It is possible that technology can be utilized to preserve fruits and vegetables that can positively contribute to this process.
\end{abstract}

Key words: stockpiled food, local self-governing body, food bank, supermarket.

\section{INTRODUCTION}

The 4th Basic Act on Shokuiku (food education) in Japan, states that Shokuiku activity should be promoted, and cooperation amongst residents, non-governmental organizations and local government is important. In Japan's local self-government, there is an overabundance of stockpiled food that will go to waste if it is unused. This food is kept stored for use in the event of disaster. While tremendous effort is dedicated to ensuring that there is food to feed Japanese citizens in the event of disaster, there has been little focus on how to effectively utilize and disseminate the stockpiled food should it go unused due to lack of disaster. Collaboration among locals, non-government organizations and food banks is imperative for the development of an action plan to reduce such large-scale food waste. The amount and items are different in each local self-government. The authors have reported the effectiveness of utilizing stockpiled food in food banks [1]. This practice is mutually beneficial for Japan's recycling laws and Shokuiku.

The nutritional value of stockpiled food was assessed and published. Daily nutrient target values were exceeded for every nutrient with the exception of vitamin $\mathrm{C}$, which is difficult to achieve [2]. However, it was also determined that stockpiled foods are high in carbohydrates and fat. If the period of refuge is long, such as in the case of the great East Japan Earthquake, foods high in vitamins and minerals must be added to stockpiled food [1]- 
[3]. For benefit of the food bank clients, improvement of the nutritional value of stockpiled food should also be considered.

In times of disaster, meal composition, particularly nutrient density, is of concern for the recipients of stockpiled foods. Local government storage facilities face the challenges of (1) achieving adequate vitamin and mineral intake and (2) procuring and utilizing fruits and vegetables that compliment stockpiled foods. The author reported that food waste in supermarkets was as high as 65\% [4]. A reduction in food waste and improvement of the stockpiled foods' nutritional value can be observed if the fruits and vegetables are used before the stockpiled food goes to waste.

In order to reduce fruit and vegetable waste, supermarkets must improve and utilize the appropriate technology. We specifically investigated technology that will extend the shelf life of supermarket fruits and vegetables. Additionally, Installation of these new tools to improve food preservation will require buy-in from the supermarket employees and effective oversight and direction by management and the Administrative Dietitian.

The purpose of this study is to survey Japanese citizens to evaluate their attitudes about providing unused stockpiled food to people via food banks. The survey also assessed their knowledge regarding its nutritional value.

\section{METHODS}

\subsection{Awareness of stockpiled food among Japanese citizens}

A survey was distributed and responses were collected via mail or e-mail during the research study period of July 2014 to October 2015. 288 Japanese men and women over the age of 20 completed the survey. The response rate was $91 \% .73 .3 \%$ of respondents identified as female, $26.4 \%$ as men and $0.3 \%$ did not disclose their gender. The majority of respondents, (45.6\%), were aged $20-29$ years. $9.8 \%$ were $30-39,17.2 \%$ were $40-49,11.6 \%$ were $50-59$ and $15.8 \%$ were over 60 years old.

\subsection{Technological information for preservation of fruits and vegetables from supermarkets}

Fruit and vegetable waste in supermarkets is substantial. By working collaboratively with local markets, fruits and vegetables that would otherwise be wasted can be transported to local food banks. To determine the best method for preserving the quality of transported foods and reducing the cost of transportation, a literature review was conducted. The literature findings indicate that dehydration is the best method because it reduces the weight of the transported food. The practice of food dehydration is becoming more widespread in Japan. Therefore, we evaluated the pros and cons associated with this method and discussed how to improve the technology.

\subsection{The purpose of economic effect and food education}

Collaboration amongst local government agencies, food banks and supermarkets are vital for effective utilization of stockpiled food. We conducted a survey about collaborative opportunities and the delivery of food education to employees and managers at 6 different supermarkets. 


\section{RESULTS}

\subsection{Japanese citizen's knowledge about the nutritional value of stockpiled food}

The results of the survey revealed that an overwhelming majority (89.9\%) of Japanese citizens do not know about the nutritional value of stockpiled food (Fig. 1). A mere $4.9 \%$ of respondents reported knowing about the nutritional value while the remainder (5.2\%) of individuals responded "other" or "no answer". Japanese citizens believe by far, that stockpiled food is most deficient in vitamins (45.1\%). Protein (13.2\%) was believed to be the second most deficient nutrient and closely behind was minerals (11.1\%). Fewer than $11 \%$ of survey respondents believed that stockpiled food was most deficient in either carbohydrate (7.3\%) or fat (3.5\%). One person said "It was insufficient in everything” (Fig. 2).

When survey participants were asked, "How do you improve the nutritional value of stockpiled food?" over half (54.5\%) thought that cooperation between supermarkets and local governments was the most effective method. Use of supplement (30.6\%) and other methods (10.4\%) were also thought to be effective means to improve the nutritional value (Fig. 3).

Acquisition of an Administrative Dietitian in towns and villages with stockpiled food would yield positive outcomes in its management. Japanese citizens agreed (75\%) that Administrative Dietitians should be involved in preparing and managing stockpiled food in an effort to reduce waste and enhance it's nutritional quality. Only a small group (4.9\%) did not think they should be involved (Fig. 4).

On the other hand, "If an accident doesn't occur, how do you use the stockpiled food at the local self-government?" Almost half (45.5\%) of the survey respondents believed that the food was wasted, $30.9 \%$ believe that it was used for emergency practice and $22.6 \%$ thought it was used in other ways (Fig. 5).

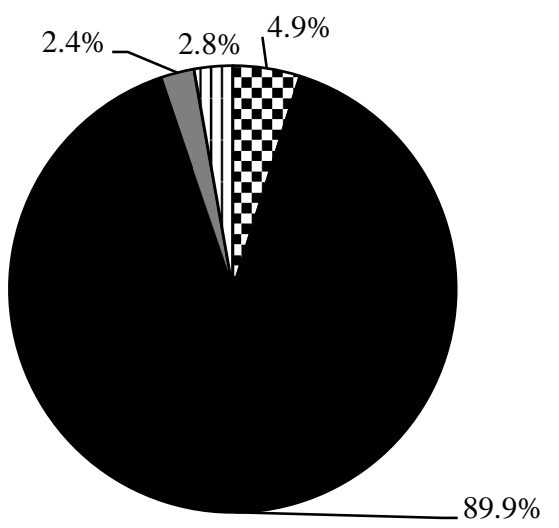

口I know

I don't know

口Others

m No answer

Figure 1: Are you informed of the nutritional value of stockpiled food in local government storage? 

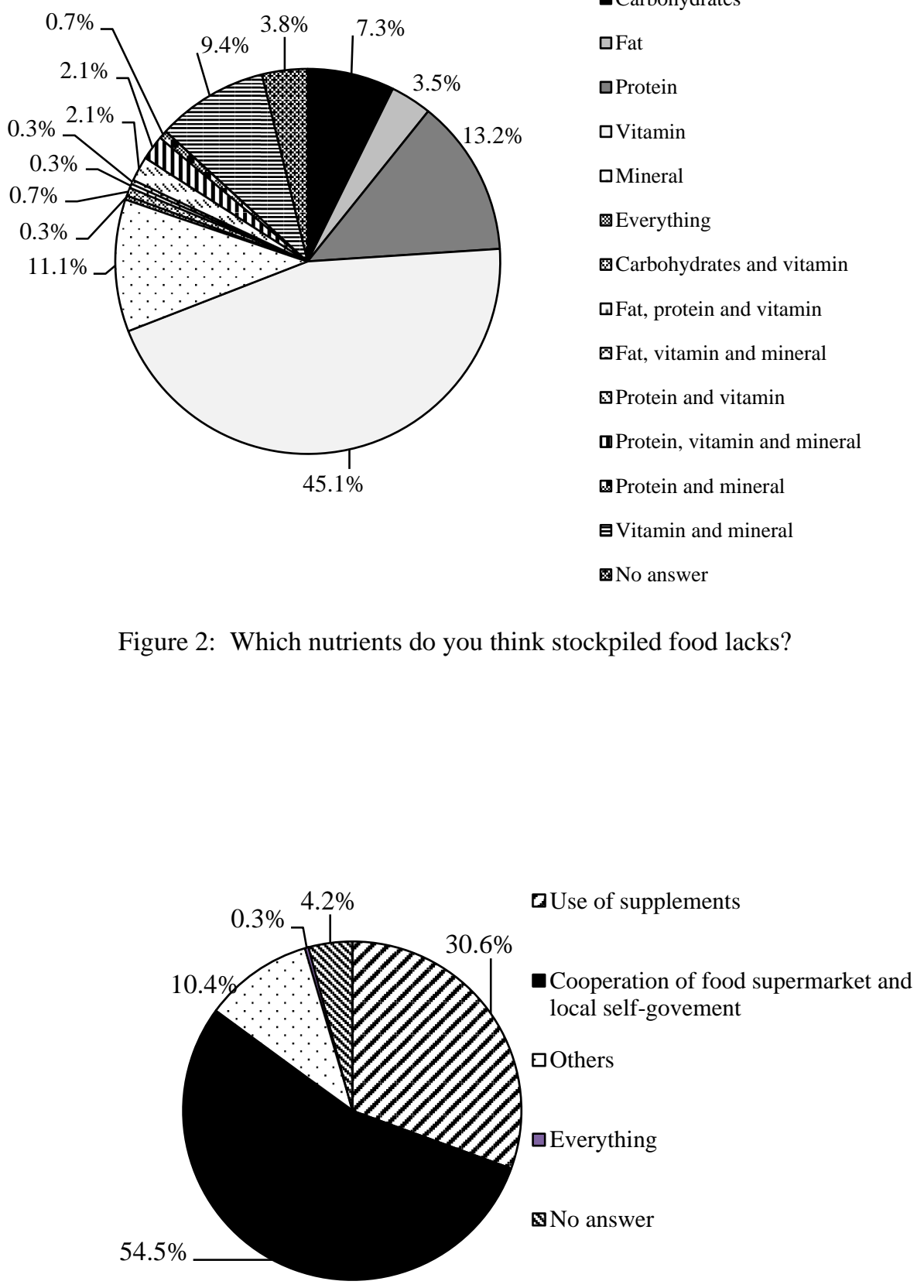

$\square$ Fat

$\square$ Protein

$\square$ Vitamin

$\square$ Mineral

․ㅡㄹ Everything

๑Carbohydrates and vitamin

$\square$ Fat, protein and vitamin

$\triangle$ Fat, vitamin and mineral

@Protein and vitamin

ם Protein, vitamin and mineral

四 Protein and mineral

目 Vitamin and mineral

No answer

Figure 2: Which nutrients do you think stockpiled food lacks?

- Carbohydrates

Figure 3: How should the nutritional value of stockpiled food be improved? 
$1.7 \%$

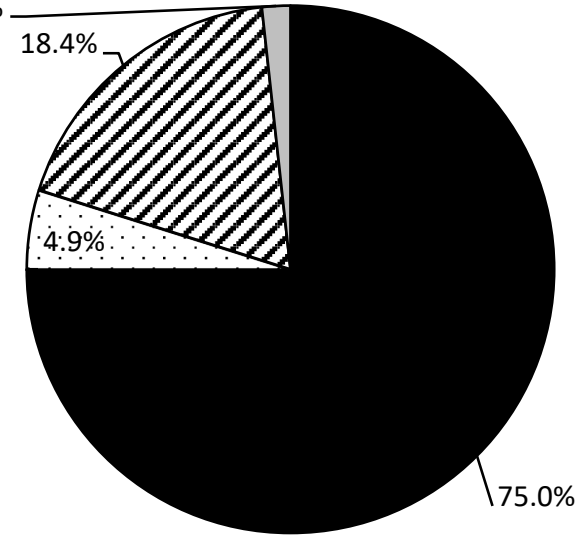

I think so

$\square$ I don't think so

[a Neither

$\square$ No answer

Figure 4: How do you think Administrative Dietitians can improve the nutritional value of stockpiled food?

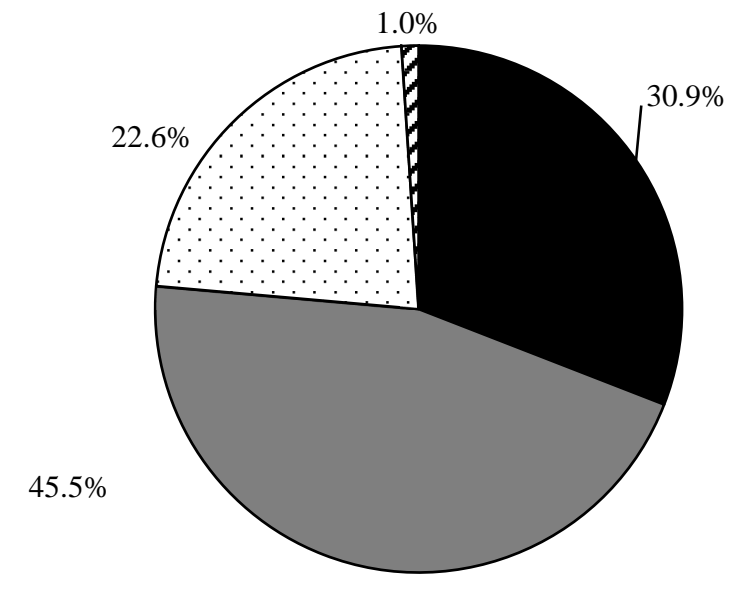

Emergency drill

$\square$ Waste

口Others

a No answer

Figure 5: If an accident doesn’£occur, how do you think the stockpiled food at the local government is used?

\subsection{Japanese citizen's awareness of food banks}

A significant number (76.7\%) of people don't know about food banks. In addition, some (22\%) are not aware of the services they provide (Fig. 6). Most citizens (48.4\%) believe that the purpose of the food bank is to provide social welfare, $35.9 \%$ believe it's purpose is to reduce food waste, and 3\% believe it serves a socioeconomic purpose (Fig. 7). 


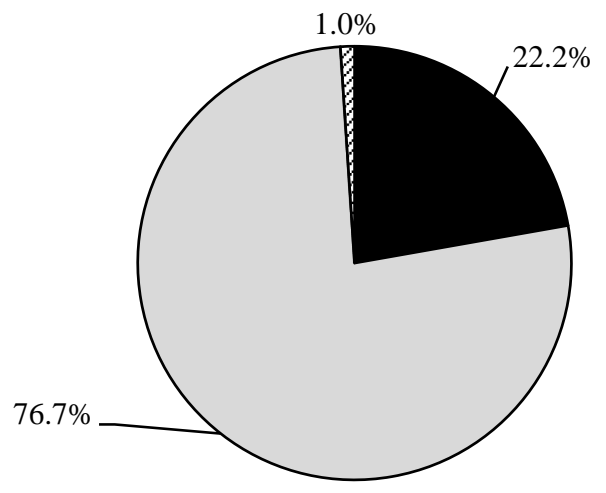

- I know

口I don't know

๑No answer

Figure 6: Do you know what food banks do?

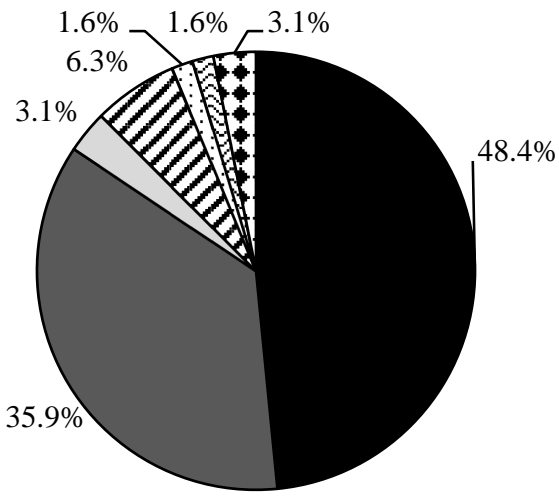

- Social welfare

$\square$ Reduction of food waste

$\square$ Area activation

$\square$ Social welfare and

Reduction of food waste

$\square$ Social welfare, Reduction of food waste and Area

activation

๑Others

Figure 7: What purpose does the food banks serve?

\subsection{Attitude survey for using stockpiled food of local self-government through food bank}

Survey respondents were asked if they agree or disagree with the local government supplying the food bank with unused stockpiled food. The majority of respondents (79.5\%) were in agreeance that providing the food bank with unused food was favorable (Fig. 8). We found that 79 people (33.5\%) approved and that many people agree that stockpiled food of a local government should be utilized for social welfare via food banks (Fig. 9). 


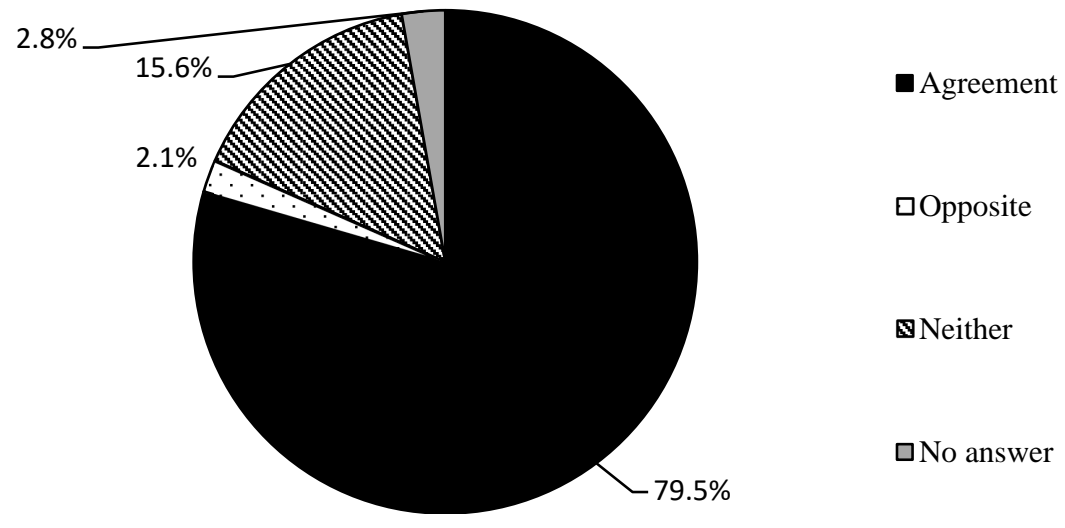

Figure 8: Do you agree with local governments supplying stockpiled food to food banks?

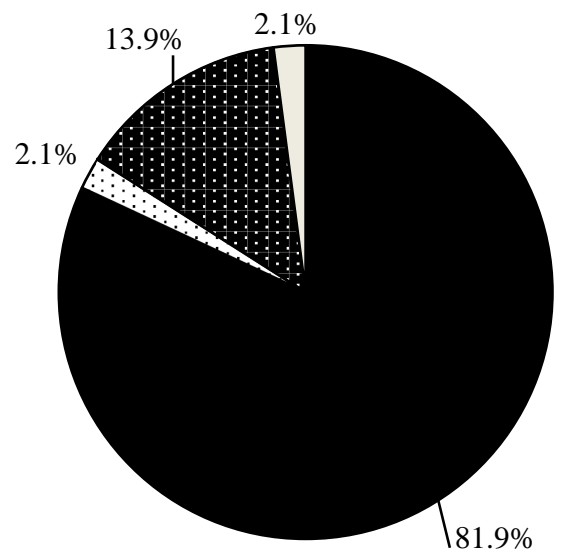

- Agreement

๑Opposite

Neither

$\square$ No answer

Figure 9: Do you agree that local governments should be involved in the activity of food banks?

3.4 Attitude survey about the involvement of country and local governments to nutritional improvement of stockpiled food

When considering a long-term refugee who utilizes stockpiled food, improvement of the nutrient density of the meals is imperative. In the United States, the United States Department of Agriculture (USDA) subsidizes food banks. Over half (54.2\%) of Japanese citizens support this practice (Fig. 10). 
Table 1: Fruit and vegetable drying methods.

\begin{tabular}{|l|l|l|l|}
\hline Shape & How to dry & Items & $\begin{array}{l}\text { Subject to be } \\
\text { studied }\end{array}$ \\
\hline $\begin{array}{l}\text { Retain } \\
\text { Natural } \\
\text { Shape }\end{array}$ & $\begin{array}{l}\text { Sun drying, } \\
\text { Convention drying, } \\
\text { Vacuum drying, } \\
\text { Vacuum } \\
\text { lyophilization }\end{array}$ & $\begin{array}{l}\text { All fruits } \\
\text { and } \\
\text { vegetables }\end{array}$ & $\begin{array}{l}\text { Blanching, } \\
\text { water } \\
\text { absorption }\end{array}$ \\
\hline Powder & Spray drying & $\begin{array}{l}\text { All fruits } \\
\text { and } \\
\text { vegetables }\end{array}$ & $\begin{array}{l}\text { Blanching and } \\
\text { spray drying } \\
\text { technologies }\end{array}$ \\
\hline
\end{tabular}

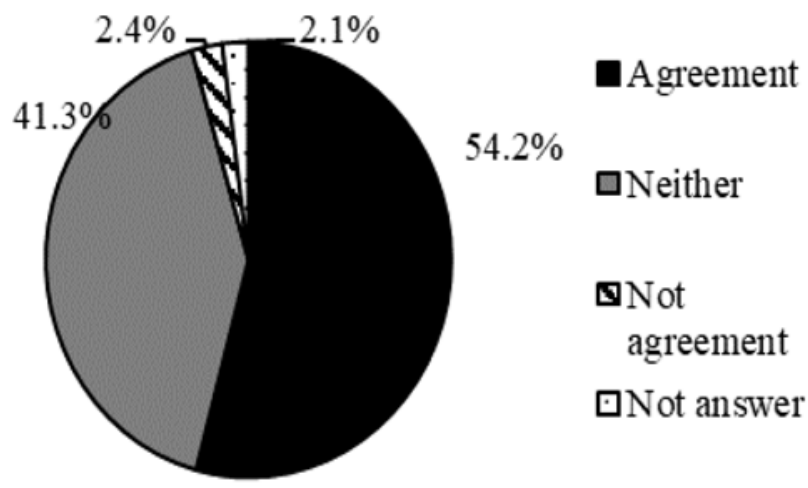

Figure 10: What do you think about the United States Department of Agriculture buying agricultural products from producers and supplying food banks?

\subsection{Technological search for fruit and vegetable preservation in supermarkets}

Supermarkets continue to make efforts to reduce fruit and vegetable waste. However, they continue to struggle to reduce the total volume of waste. Advancements to the preservation methods of these items is needed. Two effective methods are freezing and drying which can reduce the weight and volume of the food product. In turn, freezing and drying lead to reduced transportation costs. It is confirmed that preservation by dehydration is appropriate.

There are various methods for drying fruits and vegetables such as sun drying, convection drying, vacuum drying and vacuum lyophilization (Table 1). Drying methods are preferred because they do not alter the nutrient content, color, or natural form of the food even after it is rehydrated. Dried vegetables are also easily cooked and therefore, convenient for consumers. 
3.6 Survey to assess cooperation with the employees of the supermarket and food bank from the standpoint of Shokuiku

We assessed the attitudes of 6 supermarket managers (Table 2). All of the members were familiar with the concepts of Shokuiku but not all members knew about Shokuiku Fundamental Law. The majority of the managers' say that they do pay attention to the fruits and vegetables in an effort to reduce food waste. Two of them are willing to implement the new strategies within the supermarket to reduce food waste. However, 4 of them were not in agreeance because they did not have enough staff to execute the strategies in their stores. This could pose a legitimate barrier in other supermarkets as well and should be further investigated. Every manager supported providing stockpiled food to disaster victims through food banks.

\section{DISCUSSIONS}

\subsection{Improving the nutritional value of stockpiled food}

The incidence of natural disasters in Japan is high. This makes the need for stockpiled food in local-government storage all the more crucial. Stockpiled food is imperative to ensuring

Table 2: Attitude survey of Supermarket Managers on the cooperation with Shokuiku and food banks.

\begin{tabular}{|c|c|c|c|c|c|c|}
\hline $\begin{array}{l}\text { Questions to } \\
\text { manager }\end{array}$ & 1 & 2 & 3 & 4 & 5 & 6 \\
\hline $\begin{array}{l}\text { 1. Do you know food } \\
\text { fundamental law? }\end{array}$ & $\begin{array}{l}\text { I do } \\
\text { not } \\
\text { know }\end{array}$ & $\begin{array}{l}\text { I do } \\
\text { not } \\
\text { know }\end{array}$ & $\begin{array}{l}\text { I do not } \\
\text { know }\end{array}$ & $\begin{array}{c}\text { I do } \\
\text { not } \\
\text { know }\end{array}$ & $\begin{array}{l}\text { I do not } \\
\text { know }\end{array}$ & $\begin{array}{l}\text { I do not } \\
\text { know }\end{array}$ \\
\hline $\begin{array}{l}\text { 2. Do you know the } \\
\text { meaning of food } \\
\text { education? }\end{array}$ & $\begin{array}{c}\mathrm{I} \\
\text { know }\end{array}$ & $\begin{array}{c}\mathrm{I} \\
\text { know }\end{array}$ & I know & $\begin{array}{c}\mathrm{I} \\
\text { know }\end{array}$ & I know & I know \\
\hline $\begin{array}{l}\text { 3. What are you } \\
\text { doing for reduction } \\
\text { of food waste? }\end{array}$ & $※ 1$ & $※ 2$ & $\begin{array}{c}※ 1,2, \\
3\end{array}$ & $\begin{array}{l}※ 1, \\
2,3\end{array}$ & $※ 1,2, \quad 3$ & $\begin{array}{c}※ 1,2, \\
3\end{array}$ \\
\hline $\begin{array}{l}\text { 4. How do you think } \\
\text { about the use of the } \\
\text { drying technology of } \\
\text { food waste? }\end{array}$ & $※ 4$ & $\begin{array}{l}※ 5 \text {, } \\
\text { Worry } \\
\text { about } \\
\text { law }\end{array}$ & $※ 4$ & $※ 5$ & $\begin{array}{c}\text { We do not } \\
\text { use. } \\
\text { Problem } \\
\text { of the } \\
\text { label } \\
\end{array}$ & $※ 4$ \\
\hline $\begin{array}{l}\text { 5. How do you feel } \\
\text { about using fruits } \\
\text { and vegetables with } \\
\text { food stockpiled? }\end{array}$ & Agree & Agree & Agree & Agree & Agree & Agree \\
\hline $\begin{array}{l}\text { 6. How do you feel } \\
\text { about collaborating } \\
\text { with food banks and } \\
\text { local governments? }\end{array}$ & Agree & Agree & Agree & Agree & Agree & Agree \\
\hline $\begin{array}{ll}※ 1 & \text { Discount the price } \\
※ 2 & \text { Revival. } \\
※ 3 & \text { Small pack. } \\
※ 4 & \text { Problem of number }\end{array}$ & fore was & & & & & \\
\hline
\end{tabular}


that famine does not occur in times of disaster as it serves as the sole source of nourishment for Japanese citizens. Proper management to improve all of the processes related to stockpiled food such as preparation, maintenance, nutritional value, preservation and reduction of food waste are all important aspects to consider. Currently, during extended periods when Japan is free of natural disasters, all unused food is thrown away. Natural disasters are common in Japan and in the event of one occurring, many people will have to live a life of refuge. Natural disasters are impossible to predict, making it difficult to manage food waste. However, it is necessary to be equipped at all times and also prioritize the nutritional value of the stockpiled food as it serves as the primary source of nutrition for Japanese citizens in times of disaster. This is an important issue for an administrative dietitian. We think it's necessary to appeal to a national individual for future and long-term use of stockpiled food to learn how to plan for improvement of the nutritional value. Adding vitamins and minerals is necessary for longterm use of stockpiled food. Supplementing with fruits and vegetables is one option. This can be done by collaborating with supermarkets to supply fruits and vegetables that would otherwise be disposed of.

In addition, stockpiled food can be utilized for social welfare via food banks. A high number of supermarket employees were aware of food waste, but some were not. Consume health consciousness is increasing every year and the possibility of supplementing stockpiled food with fruits and vegetables for their vitamins and minerals should be considered to ensure nutritional balance. The literature indicates that there is little intake of vitamins A, B1, C and dietary fiber amongst homeless people. Insufficient intake of vitamins and minerals in the homeless population was also pointed out in UK, Paris and Toronto [6]-[9].

Authors have pointed out that stockpiled food lacks vitamins and minerals and is rich in carbohydrates and fat [1]. Cooperation with supermarkets is important for improvement of the nutritional value of stockpiled food. If improvements can be made to its nutritional value, it would then trickle down to those that utilize the food bank. It is also likely that the total fruits and vegetable waste, will be decrease.

\subsection{Collaboration amongst the food bank and supermarket}

Supplying stockpiled food to victims of disaster is important. France and Italy have laws stating that fruits and vegetables [10], [11] will be repurposed even if the item is passed the use-by date. It can be utilized for fertilizer and feed as long as it is in good quality and free of defects. They are committed to reducing food waste in supermarkets.

Government participation both nationally and locally is necessary to facilitate improvements to the use of stockpiled food. If the local government cooperates with the food banks to effectively reuse stockpiled food, great progress can be made to support the social welfare of Japanese citizens. $79.5 \%$ of Japanese citizens support donating stockpiled food to local governments and food banks. Such activity is regarded as good use of tax payer dollars.

\subsection{Reinforcement of participation of a country and a local government}

From this survey, citizens support the idea of MAFF and local governments buying agricultural products from producers or supermarkets and using them to improve the nutritional value of stockpiled food. Citizens might favor a policy that encourages the offering of fruits and vegetables from supermarkets to food banks.

Authors clearly demonstrated that food waste reduction in the food industry, i.e. supermarkets, is possible through employee education and by improving the food label [4], [12]. Fruit and vegetable disposal in supermarkets is high at about $65 \%$. In addition, the 
authors have proposed to recycle fruit and vegetable waste to be used as oil, other fats, and feed [13].

An assessment of Japanese citizen's attitudes was performed by asking the following question in a survey, "How do you feel about the government buying agricultural products from a producer, and offering it to a food bank in the USA?" The majority of citizens were in favor of it while only $2 \%$ were not. They were also asked if they were or were not in favor of the government and local government purchasing agricultural products from a producer and a supermarket in Japan and offering it to victims of disaster and/or food banks. The majority supported the idea.

There is a big difference between the value at which fruits and vegetables are bought from a producer and their value at the time the supermarket disposes of them. If the MAFF and a local government buy from a producer, it also leads to increased production and area activation especially, economic activation of farm villages. It's expected that it's also tied with local government and producers by buying fruit and vegetables of disposal immenseness from a supermarket. These activities are aligned with reduction of the amount of waste, the cost reduction concerned with burning and reduction of environmental load and the big effect for local government.

\subsection{Supermarket techniques to conserve fruits and vegetables}

Suitable processing is necessary for long-term storage of fruits and vegetables. Fermentation, drying and freezing are all preservation methods that can be utilized. To improve the roundtrip cost and ease of transportation, drying is effective and preferred because it reduces the food weight thus reducing transportation expenses [5]. Introducing effective drying techniques is necessary for reducing fruit and vegetable waste in supermarkets. Dehydrated food has already been developed. If the fruits and vegetables are ground into powder, their shelf-life is extended. Since fruits and vegetables are rich in vitamins and minerals, their powder form can be added to meals to make them more nutritious.

Various reports indicate that even after drying, the vitamins in vegetables, especially vitamin $\mathrm{C}$, remain intact. Vacuum lyophilization has proven to maintain the natural shape, color and nutrient content of paprika, spinach, parsley, broccoli and field peas. A report showed that with this process, vitamin $C$ levels were the highest in all of the above thus making it one of the more favorable preservation options. However, one consideration is the affect that this process has on the taste and smell of these foods [15].

Therefore, drying period reduction using a microwave is studied in recent years. The degradation of fruits and vegetables during and after processing happens as a result of the breakdown of several enzymes [14], [15]. Therefore, when producing high-quality fruits and vegetables, blanching should be used because it suppresses enzyme activity and stops the degradation process [16]. Exposure to boiling water has mainly been used for conventional blanching of fruits and vegetables and water-soluble materials [16]. However, the quality may suffer due to changes in pigmentation and structural weakening. Therefore, since the food's nutritional value and characteristics may be compromised during processing, utilizing microwaves was studied to explore it's use as an alternative [17]. Microwaves and blanching are able to reduce processing time and the extent of degradation that occurs via rapid heating.

As was mentioned above, evidence supports the possibility of retaining the nutritional properties of fruits and vegetables [17]. Tomatoes were exposed to two boiling water conditions: (1) in a microwave and (2) out of the microwave. In the incidences where the microwave was used, enzyme inactivation occurred much faster [17] Also, the color, lycopene and ascorbic acid content of the tomatoes remained unaffected [16]. Drying technology can 
be introduced to supermarkets in the future. Administrative Dietitians can advocate and have a great impact on the introduction of these methods for fruits and vegetables.

\subsection{The influence of Shokuiko on social welfare, the economy, and environmental impact}

Local governments keep stockpiled food for emergencies year-round. Devising a distribution plan for periods without disaster is important so as to not waste the food when it goes unused. Plans for redistribution should include strengthening collaborative relationships with food banks, local governments and supermarkets to meet food access needs within communities. Social welfare efforts are greatly supported by and congruent with the values of Japanese citizens. The support and engagement of the respective community, local government, and Administrative Dietitian (AD) across Japan is vital to the realization of such an idea.

Employment of an AD is advanced in Japan. AD's are able to foster relationships between the supermarket and food bank to reduce food waste and provide valuable insight to improve the nutritional quality of stockpiled foods. In addition, the AD is able to promote Shokuiku to improve the outcomes of the food waste efforts. Their role in the process is vital to its success.

\subsection{Possibility of supermarket cooperation with stockpiled food}

Supermarket managers agreed to contribute fruits and vegetables to supplement the stockpiled food thereby improving its nutritional value. However, there is a lack of understanding about the Shokuiku fundamental law which is the foundation for collaboration. One of the greatest barriers to implementation is insufficient staff. A savvy and experienced manager is needed to come up with creative solutions to overcome the barriers to implementation.

\subsection{The role of the administrative dietitian}

The AD should be expected to provide nutrition education to the victims of disaster. Various information about the nutrition of the meal which is at the time of accident occurrence has been published [19]. Providing detailed information is necessary. The AD can also provide specialized nutritional care to individuals under medical treatment and in nursing facilities. The AD can determine the nutritional value of specific foods and meals and determine if they are appropriate on a patient by patient basis [20].

\section{ACKNOWLEDGEMENT}

The authors would like to thank Natalie Martinez for her diligent support in editing the manuscript.

\section{REFERENCES}

[1] Sato, M., Nakano, M., Gatto, M. \& Wunderlich, S., Nutritional and environmental considerations of food stockpiles in Japan and USA: Reducing food waste by efficient reuse through the food banks. International Journal of Sustainable Development Planning, 11(6), pp. 980-988, 2016.

[2] Ito, T., Recipes and nutritional evaluation of the disaster food [in Japanese]. Journal of Japan Disaster Food Society, 2(1), pp. 19-25, 2015.

[3] Watanabe, S., Food and nutritional problems following the great east Japan earthquake and tsunami disaster conclusion, Kenpakusha, pp. 143-148, 2011. 
[4] Sato, M. \& Nakano, M., Analysis of food waste in supermarket store and research for employees an attitude survey for reducing food waste [in Japanese with English summary]. Journal of Japanese Society of Shokuiku, 7(4), pp. 259-283, 2013.

[5] Tamaki, Y., Orikasa, T., Muramatu, Y. \& Tagawa, A., Effects of vegetable porosity following microwave drying on absorption of dried vegetables [in Japanese]. Nippon Shokuhin Kogaku Gakkaishi, 59(8), pp. 401-408, 2012.

[6] Tahara, T., Tabuchi, T., Harihara, S., Bandoh, T. \& Ido, T., Nutritional characteristics of homeless people in Airin district, Osaka: Comparison with people on welfare [in Japanese]. The Japanese Society of Nutrition and Dietetics, 69(1), pp. 29-38, 2011.

[7] Sprake, E.F., Russelt, J.M. \& Barker, M.E., Food choice and nutrient intake amongst homeless people. Journal of Human Nutrition and Dietetics, 27, pp. 242-250, 2014

[8] Malmauret, L., Leblanc, J.C.H., Cuvelier, I. \& Veger, P.H., Dietary intake and vitamin status of a sample of homeless people in Paris. European Journal of Clinical Nutrition, 56, pp. 313-320, 2002.

[9] Tse, C. \& Tarasuk, V., Nutritional assessment of charitable meal programs serving homeless people in Toronto. Public Heath Nutrition, 11(12), pp. 1296-1305, 2008

[10] Mainichi newspaper, France unsold food waste ban, 17 Feb., 2016. http://mainichi.jp/articles/20160218/k00/00m/030/016000c.

[11] Independent HP. www.independent.co.uk/news/world/europe/italy-food-waste-lawsupermarkets-a6931681.html.

[12] Sato, M. \& Nakano, M., The display on food product influencing the reduction of the amount of food waste [in Japanese with English summary]. Journal for the Integrated Study of Dietary Habits, 23(3), pp. 166-173, 2012.

[13] Sato, M. \& Nakano, M., Exploitation of food waste resources in food retailers using laws and consumer awareness-finding suitable resource systems for zero-emission. World Academy of Science, Engineering and Technology, 71, pp. 2023-2028, 2012.

[14] Osada, S., Tonozuka, F., Tani, T., Negishi, Y., Okuzaki, M. \& Kagawa, Y., Basic cooking and processing properties of Aquagas-treated food materials (Part 5): Using carrots [in Japanese]. Journal for the Integrated Study of Dietary Habits, 19(3), pp. 239-246, 2008.

[15] Yamagishi, A., Nishi, R., Hirose, J., Urabe, K. \& Nadamoto, T., Changes in food items because of processing with different drying methods [in Japanese]. Food Preservation Science, 38(3), pp. 169-176, 2012.

[16] Ando, Y. et al., Application of microwave to drying and blanching of tomatoes [in Japanese]. Nippon Shokuhin Kogyou Gakkaishi, 57(5), pp. 191-197, 2010.

[17] Yamada, Y., The dried vegetable for which a microwave was used and development of a production technique of fruit. Technical report of Japan Food Industry Center, 29, pp. 478-485, 2002.

[18] Consumer Affairs Agency, Government of Japan, No. 9 and No. 10. http://law.egov.go.jp/htmldata/H17/H17HO063.html.

[19] Okuda, K., What is disaster food: Subject and outlook in future. Journal of Japan Disaster Food Society, 1(1), pp. 1-12, 2014.

[20] Matutuki, H., Konno, A., Hosoya, R., Sasaki, R., Matumoto, M. \& Muto, T., Problem of disaster measures at food service centers of medium and small-scale medical and care facilities. Journal of Japan Disaster Food Society, 1(1), pp. 13-20, 2014. 